\title{
Diarrhoea in general practice: a sixteen-year report of investigations in a microbiology laboratory, with epidemiological assessment
}

\author{
By MAIR E. M. THOMAS AND HILARY E. TILLETT \\ Epidemiological Research Laboratory, Central Public Health Laboratory, \\ Colindale Avenue, London, NW9 5HT
}

(Received 18 September 1974)

\section{SUMMARY}

Results are presented of the laboratory examination of faeces specimens from 20,273 patients with acute diarrhoea. These were household index cases seen in general practice in a London borough during the years 1953-68. An annual average of about $2 \%$ of households in the area were affected, but there was considerable fluctuation with year and season. Half the patients were children although only one-fifth of the population at risk was under 15 years of age. The greatest incidence of diarrhoea was among children under 5 years old. Male children, but female adults predominated.

Specimens were sent for laboratory diagnosis at the discretion of the general practitioner. The laboratory found some abnormality in nearly a third and there were indications that transmissible infection was involved in about one-fifth of patients. The most common diagnosis was Sonne dysentery (9\%) which came in epidemic waves and made its greatest impact among young school children. Microscopy was useful, and giardiasis was diagnosed in $1.4 \%$ of index patients. Other parasites were less commonly found. Fatty globules characteristic of an infectious condition we have called 'fatty diarrhoea' were frequently observed by microscopy in stools from young children and occasionally from older persons. Blood or pus cells were seen in less than half the shigella and salmonella infections and in a much smaller proportion of the remainder. A test for occult blood performed on specimens from all patients of 40 years or older was positive, in the absence of visible red cells, in a tenth of these cases.

Other studies on the bacteriology of diarrhoea in general practice are referred to and some epidemiological comparisons made. The possible place of unidentified infective agents in the aetiology of undiagnosed diarrhoeas and of 'fatty diarrhoea' is discussed.

\section{INTRODUCTION}

A study of causes of diarrhoeal illness seen in general practice has been made by a retrospective search of routine records kept in a Public Health Laboratory in north London. The records covered a sixteen-year period, 1953-68. The population served by this laboratory was about 274,000 . The area was the present London 
Borough of Enfield. A very few specimens came to the laboratory from patients living outside this area.

General practitioners were encouraged to submit specimens for laboratory diagnosis from patients with acute gastro intestinal symptoms. The readiness with which they used this service varied from practice to practice. However, the years of investigation cover a period when there was a fairly stable 'population' of general practitioners and Medical Officers of Health. Use of the laboratory was recorded annually and it was found that most individual practitioners were consistent in the amount of use which they made of the facilities available, so that inferences can be drawn from these records about relative changes of disease pattern with time.

Analyses of records from this laboratory concerning households in which salmonella or Sonne dysentery infections were diagnosed have already been reported (Thomas \& Mogford, 1970; Thomas \& Tillett, 1973a,b).

\section{METHODS}

Each first, diagnostic faeces specimen was examined by direct microscopy and then cultures were made on MacConkey and on deoxycholate citrate agar, and from selenite-F enrichment broth on deoxycholate citrate agar. Standard biochemical and serological methods were used for identification of pathogens. Enteropathogenic Escherichia coli were not usually sought except in children of pre-school age. Clostridium welchii and Staphylococcus aureus were sought only in specimens from outbreaks of suspected food poisoning. A benzidine test for occult blood was performed on faeces from patients aged 40 years and over, and repeated prepared specimens requested when the test was positive.

During this sixteen-year period the laboratory investigated about 170,000 faeces specimens (estimated at about 5 tons). The laboratory records selected for the present analysis were those relating to first specimens received for diagnosis from the index (first) patient with diarrhoea to be seen by the general practitioner in a particular household, and these represented $12 \%$ of the total specimens examined. Records concerning household contacts were excluded, as were those of specimens sent by the public health authorities for investigation or follow-up. The routine records, kept in the laboratory day book, included information identifying the patient, the practitioner, symptoms and duration of illness where known, results of microscopy, culture, biochemical tests and the final report sent to the doctor.

\section{RESULTS}

During the years 1953-68, 20,273 index cases of acute diarrhoea were investigated at the laboratory for general practitioners. The number studied in a year varied between 889 and 1883 . The age and sex distribution of these patients is shown in Table 1. About half the index cases were children under 15 years of age and half adults. Most of the children were in the pre-school age group and few were in the group 10-14 years. There were more cases among boys than girls. However, 
Table 1. Total specimens received for diagnosis from index cases, 1953-1968, according to age and sex of patients

$\begin{array}{cccc}\text { Age in years } & \text { Male } & \text { Female } & \text { Total } \\ 0-4 & 3,231(15 \cdot 9) & 2,422(11 \cdot 9) & 5,653(27 \cdot 9) \\ 5-9 & 1,890(9 \cdot 3) & 1,516(7 \cdot 5) & 3,406(16 \cdot 8) \\ 10-14 & 787(3 \cdot 9) & 555(2 \cdot 7) & 1,342(6 \cdot 6) \\ 15-39 & 2,109(10 \cdot 4) & 2,647(13 \cdot 1) & 4,756(23 \cdot 5) \\ \geqslant 40 & 1,964(9 \cdot 7) & 2,749(13 \cdot 6) & 4,713(23 \cdot 2) \\ \text { Not known } & 193(1 \cdot 0) & 210(1 \cdot 0) & 403(2 \cdot 0) \\ \text { Total } & 10,174(50 \cdot 2) & 10,099(49 \cdot 8) & 20,273(100 \cdot 0)\end{array}$

Figures in parentheses are percentages.

Table 2. Total specimens received for diagnosis, 1953-68, according to laboratory findings

\begin{tabular}{|c|c|c|c|c|c|c|}
\hline \multirow[b]{2}{*}{ Laboratory findings } & \multirow[b]{2}{*}{$\begin{array}{l}\text { Blood and } \\
\text { pus cells }\end{array}$} & \multirow{2}{*}{$\begin{array}{l}\text { Blood } \\
\text { cells } \\
\text { only }\end{array}$} & \multirow[b]{2}{*}{$\begin{array}{l}\text { Pus cells } \\
\text { only }\end{array}$} & \multirow[b]{2}{*}{$\begin{array}{l}\text { No cells } \\
\text { found }\end{array}$} & \multicolumn{2}{|c|}{ Total } \\
\hline & & & & & No. & $\begin{array}{l}\% \text { of all } \\
\text { specimens }\end{array}$ \\
\hline Sonne dysentery & $\begin{array}{c}491 \\
(26 \%)\end{array}$ & $\begin{array}{c}22 \\
(1 \%)\end{array}$ & $\begin{array}{c}252 \\
(14 \%)\end{array}$ & $\begin{array}{c}1,101 \\
(59 \%)\end{array}$ & 1,866 & $9 \cdot 2 \%$ \\
\hline Salmonellosis & $\begin{array}{c}142 \\
(30 \%)\end{array}$ & $\stackrel{2}{(-)}$ & $\begin{array}{c}53 \\
(11 \%)\end{array}$ & $\begin{array}{c}278 \\
(58 \%)\end{array}$ & 475 & $2 \cdot 3 \%$ \\
\hline E. coli & $\begin{array}{c}9 \\
(4 \%)\end{array}$ & - & $\begin{array}{c}7 \\
(3 \%)\end{array}$ & $\begin{array}{c}216 \\
(93 \%)\end{array}$ & 232 & $1 \cdot 1 \%$ \\
\hline Giardiasis & $\begin{array}{c}7 \\
(2 \%)\end{array}$ & $\begin{array}{c}4 \\
(1 \%)\end{array}$ & $\begin{array}{c}9 \\
(3 \%)\end{array}$ & $\begin{array}{c}268 \\
(93 \%)\end{array}$ & 288 & $1 \cdot 4 \%$ \\
\hline Other pathogens & $\begin{array}{c}16 \\
(13 \%)\end{array}$ & $\begin{array}{c}3 \\
(2 \%)\end{array}$ & $\begin{array}{c}8 \\
(7 \%)\end{array}$ & $\begin{array}{c}95 \\
(78 \%)\end{array}$ & 122 & $0.6 \%$ \\
\hline Fatty diarrhoea & $\begin{array}{c}8 \\
(1 \%)\end{array}$ & $\stackrel{4}{(-)}$ & $\begin{array}{c}18 \\
(1 \%)\end{array}$ & $\begin{array}{c}1,335 \\
(98 \%)\end{array}$ & 1,365 & $6 \cdot 7 \%$ \\
\hline No dirgnosis & $\begin{array}{c}1,236 \\
(8 \%)\end{array}$ & $\begin{array}{l}247 \\
(2 \%)\end{array}$ & $\begin{array}{c}565 \\
(4 \%)\end{array}$ & $\begin{array}{c}14,028 \\
(87 \%)\end{array}$ & 16,076 & $79 \cdot 3 \%$ \\
\hline Total results & 1,909 & 282 & 912 & 17,321 & $20,424^{*}$ & \\
\hline Total specimens & $\begin{array}{c}1,898 \\
(9 \%)\end{array}$ & $\begin{array}{l}281 \\
(1 \%)\end{array}$ & $\begin{array}{l}901 \\
(4 \%)\end{array}$ & $\begin{array}{c}17,193 \\
(85 \%)\end{array}$ & $\begin{array}{l}20,273 \\
(100 \%)\end{array}$ & \\
\hline
\end{tabular}

* Including 143 double and 4 triple diagnoses.

among adults there were more females than males. Approximate average annual incidence rates of index cases per 10,000 population were 204 in age group 0-4 years, 139 for 5-9 years old, 41 for 10-14 year olds, 31 for 15-39 year olds, 23 for $40+$ year olds and 46 in all. Diagnostic specimens were sent to the laboratory from general practitioners from an annual average of about $2 \%$ of households in the area.

The results of laboratory investigation of the faeces are shown in Table 2. Nothing abnormal was found in 14,028 (69\%) of the cases. A conventional recognized infection was reported in $15 \%$ of cases. In the remaining $16 \%$ of cases other findings of clinical use were demonstrated by microscopy or chemical tests. 
Table 3. Laboratory diagnosis according to age group of patients

\begin{tabular}{|c|c|c|c|c|c|c|}
\hline $\begin{array}{c}\text { Laboratory } \\
\text { diagnosis }\end{array}$ & $\begin{array}{c}0-4 \\
\text { years }\end{array}$ & $\begin{array}{c}5-9 \\
\text { years }\end{array}$ & $\begin{array}{l}10-14 \\
\text { years }\end{array}$ & $\begin{array}{l}15-39 \\
\text { years }\end{array}$ & $\begin{array}{l}\geqslant 40 \\
\text { years }\end{array}$ & $\begin{array}{l}\text { Age not } \\
\text { known }\end{array}$ \\
\hline Sonne dysentery & $\begin{array}{c}412 \\
(7 \cdot 3 \%)\end{array}$ & $\begin{array}{c}850 \\
(25 \cdot 0 \%)\end{array}$ & $\begin{array}{c}171 \\
(12 \cdot 7 \%)\end{array}$ & $\begin{array}{c}282 \\
(5.9 \%)\end{array}$ & $\begin{array}{c}128 \\
(2 \cdot 7 \%)\end{array}$ & $\begin{array}{c}23 \\
(5 \cdot 7 \%)\end{array}$ \\
\hline Salmonellosis & $\begin{array}{c}142 \\
(2 \cdot 5 \%)\end{array}$ & $\begin{array}{c}90 \\
(2 \cdot 6 \%)\end{array}$ & $\begin{array}{c}32 \\
(2 \cdot 4 \%)\end{array}$ & $\begin{array}{c}112 \\
(2 \cdot 4 \%)\end{array}$ & $\begin{array}{c}95 \\
(2 \cdot 0 \%)\end{array}$ & $\begin{array}{c}4 \\
(1 \cdot 0 \%)\end{array}$ \\
\hline E. coli & $\begin{array}{c}232 \\
(4-1 \%)\end{array}$ & \multicolumn{5}{|c|}{ (Not routinely looked for) } \\
\hline Giardiasis & $\begin{array}{c}66 \\
(1 \cdot 2 \%)\end{array}$ & $\begin{array}{c}55 \\
(1 \cdot 6 \%)\end{array}$ & $\begin{array}{c}20 \\
(1 \cdot 5 \%)\end{array}$ & $\begin{array}{c}78 \\
(1 \cdot 6 \%)\end{array}$ & $\begin{array}{c}63 \\
(1 \cdot 3 \%)\end{array}$ & $\begin{array}{c}6 \\
(1.5 \%)\end{array}$ \\
\hline Other pathogens & $\begin{array}{c}35 \\
(0.6 \%)\end{array}$ & $\begin{array}{c}12 \\
(0 \cdot 4 \%)\end{array}$ & $\begin{array}{c}9 \\
(0 \cdot 7 \%)\end{array}$ & $\begin{array}{c}38 \\
(0 \cdot 8 \%)\end{array}$ & $\begin{array}{c}24 \\
(0.5 \%)\end{array}$ & $(1 \cdot 0 \%)$ \\
\hline Fatty diarrhoea & $\begin{array}{c}979 \\
(17 \cdot 3 \%)\end{array}$ & $\begin{array}{c}117 \\
(3 \cdot 4 \%)\end{array}$ & $\begin{array}{c}34 \\
(2 \cdot 5 \%)\end{array}$ & $\begin{array}{c}122 \\
(2 \cdot 6 \%)\end{array}$ & $\begin{array}{c}95 \\
(2.0 \%)\end{array}$ & $\begin{array}{c}18 \\
(4.5 \%)\end{array}$ \\
\hline $\begin{array}{l}\text { Blood or pus } \\
\text { cells only }\end{array}$ & $\begin{array}{c}329 \\
(5 \cdot 8 \%)\end{array}$ & $\begin{array}{c}241 \\
(7 \cdot 1 \%)\end{array}$ & $\begin{array}{c}105 \\
(7 \cdot 8 \%)\end{array}$ & $\begin{array}{c}532 \\
(11 \cdot 2 \%)\end{array}$ & $\begin{array}{c}791 \\
(16 \cdot 8 \%)\end{array}$ & $\begin{array}{c}50 \\
(12 \cdot 4 \%)\end{array}$ \\
\hline $\begin{array}{l}\text { No abnormal } \\
\text { findings }\end{array}$ & $\begin{array}{c}3543 \\
(62 \cdot 7 \%)\end{array}$ & $\begin{array}{c}2072 \\
(60 \cdot 8 \%)\end{array}$ & $\begin{array}{c}980 \\
(73.0 \%)\end{array}$ & $\begin{array}{c}3608 \\
(75.9 \%)\end{array}$ & $\begin{array}{c}3527 \\
(74 \cdot 8 \%)\end{array}$ & $\begin{array}{c}298 \\
(73 \cdot 9 \%)\end{array}$ \\
\hline Total cases* & $\mathbf{5} 653$ & 3406 & 1342 & 4756 & 4713 & 403 \\
\hline
\end{tabular}

Examination by microscopy did not often reveal the presence of blood or pus in the stools, except in cases where Shigella sonnei or a salmonella was isolated and, even among these cases, over half were acellular.

\section{Bacterial infections}

The most frequent positive diagnosis was Sonne dysentery $(9 \cdot 2 \%$ of cases $)$. Other bacterial infections were found less commonly $-2 \cdot 3 \%$ of cases had salmonellosis and there were $232 E$. coli infections in children of pre-school age. Seven other infections with enteropathogenic serotypes of $E$. coli which were found in older children and adults have been counted among the 'other' pathogens, since they were not routinely sought in these age groups.

In Table 2, 83 named bacteria are included under the heading 'other' pathogens. These were 32 Proteus rettgeri, 18 providencia species, 10 alkalescens species, the seven $E$. coli infections in older age groups, five $C l$. welchii, four each of Sh.flexneri and bethesda species, and one each of Staph. pyogenes, arizona species and hafnia species. Cl. welchii and Staph. pyogenes were always sought in outbreaks of food poisoning, but seldom from sporadic cases of gastroenteritis referred by general practitioners.

\section{Parasites}

A total of 322 protozoal infections were recognized. Giardia lamblia was found in 288 or $1.4 \%$ of cases. The other protozoal infections included 29 Entamoeba histolytica, 3 Trichomonas hominis, one each of Endolimax nana and Chilomastix 


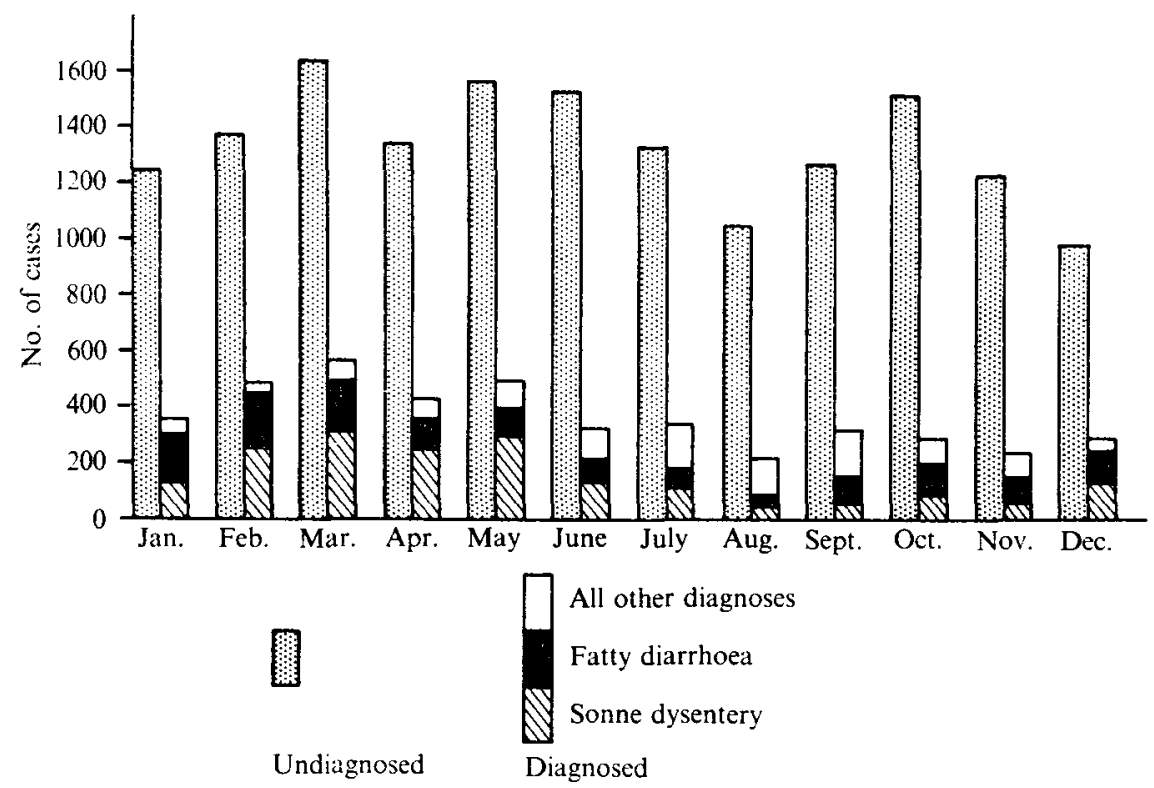

Fig. 1. Number of cases investigated according to month and diagnosis.

mesnili. In addition 4 Enterobius vermicularis and one Taenia saginata were recorded.

\section{Fatty diarrhoea}

In $6.7 \%$ of cases profuse fat globules, or their derivatives such as fatty acid crystals were observed. These are typical of a condition which has been reported as infectious in behaviour, but for which no pathogen has been found (Thomas, 1952). These cases are grouped under the description 'fatty diarrhoea'.

\section{Multiple infection}

In 56 cases two pathogenic organisms were isolated from the diagnosis specimen and three of these had 'fatty diarrhoea' in addition - and in one case three pathogens were identified. A further 90 cases had signs of 'fatty diarrhoea' as well as a bacterial pathogen or parasite. A study of these cases showed that the incidence of 'fatty diarrhoea' was not associated with any of the pathogens routinely looked for, which suggests that it represents a separate disease entity.

\section{Age groups}

Table 3 summarizes laboratory findings in different age groups. The results from males and females were similar (except that there were more male cases of giardiasis) and they have therefore been added together. A positive diagnosis was more common in children under 10 years than in older persons. Nearly half the Sonne dysentery infections were in school children aged 5-9 years, where they accounted for $25 \%$ of cases investigated, and nearly a quarter were in pre-school children aged 0-4 years, where dysentery accounted for $7 \%$ of cases of diarrhoea. 


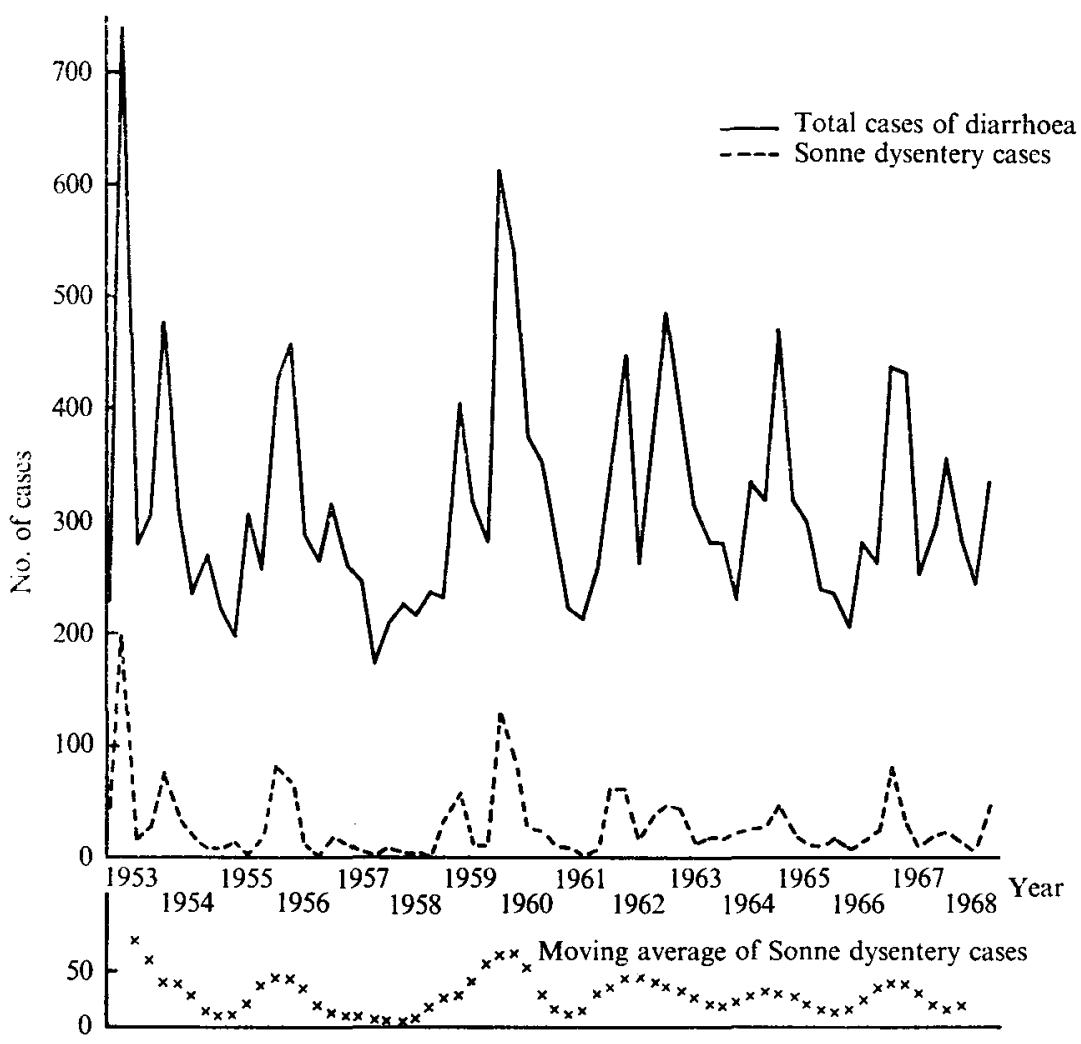

Fig. 2. Total cases investigated in each quarter, and number diagnosed as Sonne dysentery.

Salmonella infection was found in about $2 \%$ of cases in all age groups and giardiasis in between 1 and $2 \%$, with 164 cases in males and 124 in females. The fatty diarrhoea was most frequently seen in the $0-4$ year age group, where the condition was observed in as many as $17 \%$ of cases. Fatty diarrhoea took second place to Sh. sonnei as the most common positive finding, excluding blood and pus cells, in all other age groups.

The proportion of cases for which no diagnosis was made but where blood or pus cells were seen in the stools increased with age from $5.8 \%$ in the pre-school group to $16.8 \%$ in adults of 40 years or more.

\section{Occult blood}

It was the practice to test for occult blood in diagnosis specimens from patients aged 40 years or more, unless red cells had already been seen by microscopy. Occult blood was detected in $238(12 \cdot 1 \%)$ of the 1964 specimens from males and in 270 $(9 \cdot 8 \%)$ of 2,749 specimens from females in this age group. This larger rate for males is significant $(P<0 \cdot 05)$. Most positive findings were in patients from whom no pathogen was isolated, but the rate did not vary much between different diagnostic groups. 


\section{Seasonal and annual incidence}

The numbers of diagnosed and undiagnosed cases investigated during the sixteen years are shown in Fig. 1, according to the month in which the specimen was received at the laboratory. (The median time from onset of symptoms to the collection of a diagnosis specimen was three days.) The seasonal pattern of Sonne dysentery, with epidemics occurring in winter and spring, has already been noted (Thomas \& Tillett, 1973a). The increase in 'other' diagnosed cases in summer months was almost entirely due to the increase in salmonellosis cases, since giardiasis and $E$. coli infections showed little seasonal variation. The pattern of undiagnosed cases, and also that of fatty diarrhoea, tended to follow the pattern of Sonne dysentery from January to August, but with an additional rise in autumn.

Fig. 2 shows the total numbers of cases investigated and numbers diagnosed as Sonne dysentery in successive quarters for the 16 years. A four point, centred, moving average of dysentery cases is also shown, which plots trend by smoothing out seasonal fluctuations. Sonne dysentery appears to have affected the community in epidemic waves which reached a peak every two to three years. Although dysentery accounted for only $9 \cdot 2 \%$ of all the cases, the fluctuations seen in Sonne dysentery are reflected in the total cases. The correlation coefficient $(r)$ for total and Sonne cases in the 64 quarters is 0.80 which is highly significant. Since the square of the correlation coefficient represents that proportion of variation in the first variable which is accounted for by variation in the second variable, the variation in Sonne dysentery cases may be said to have 'explained' $64 \%$ of the variation in total cases investigated. This contrasts sharply with the finding that Sonne dysentery cases contributed only $9 \%$ of actual numbers of cases.

\section{DISCUSSION}

Many diarrhoeal illness never reach the attention of a doctor (Tuckman et al. 1962). Even so diarrhoea is a common cause of certified sickness absence (Walker \& Robertson, 1968) and sometimes serious illness in infants (D.E.S. \& D.H.S.S., 1971). In a national study of morbidity statistics from sample practices in England and Wales lasting 12 months during 1955 and 1956, 2.9 consultations per 100 patients on the practice list were specifically recorded as the diarrhoeal illnesses, dysentery, food poisoning, gastroenteritis and diarrhoea, with or without vomiting (Logan \& Cushion, 1958). Since 1967 the Royal College of General Practitioners research unit have published weekly consultation rates in a sample of practices covering a population of about 150,000 patients. In both 1967 and 1968 the annual rate of new consultations for gastroenteritis was 2 per 100 list patients.

The index cases analysed in this report represented leading cases of gastroenteritis in households in Enfield from 1953 to 1968 and indicate the distribution of disease within an urban community. They represented about 2 per 100 households per year. Index cases averaged an annual rate of 0.46 per 100 population. It is not known how many other persons were ill in these households but our analyses of shigella and salmonella infections in the same area indicated that each shigella 
index infection represented on average two infections and each salmonella $1 \cdot 6$ infections (Thomas \& Tillet, $1973 a$; Thomas \& Mogford, 1970). These two conditions were notified to the public health department and the subsequent statutory powers made the ascertainment of contact infections possible. This was not possible for other conditions, but sample studies of contacts revealed plural cases in the households of other diarrhoeal infections, including fatty diarrhoea.

The proportion of cases seen by general practitioners referred to the laboratory is unknown. It is therefore interesting to consider how representative of all diarrhoeal cases were those having laboratory investigation. Other surveys have been reported in Britain during the same period in which all consulting patients, whether index cases or not, were investigated bacteriologically. Some comparisons can be made although different populations are involved, and these surveys cover periods of time too short to show the considerable fluctuation we observed from year to year.

In a group practice in Kent (Tuckman et al. 1962) the annual incidence of diarrhoeal illnesses was $5 \cdot 8 \%$ in 1957 when Sonne dysentery was prevalent and $4.5 \%$ in 1958 , which was virtually dysentery-free. During these years investigation of 622 cases revealed $S h$. sonnei in $18 \%$ and salmonella in 3 cases and $E$. coli in 7 cases. Case rates were much higher for children than for adults. The ratio of all child to adult cases was high, and higher than we found among index cases. Male children and female adults predominated. Sonne dysentery rates were highest among school children, whose presence in the family increased the chance of finding $S h$. sonnei. We have previously emphasized the importance of primary schools in the spread of Sonne dysentery through a community (Thomas \& Tillett, $1973 b)$. Tuckman seldom observed blood and pus cells except in the Sonne cases and even among these in less than half.

In another urban practice survey made in 1951 Smither (1953) examined rectal swabs from 90 unselected cases of gastroenteritis. Eighty-six per cent were undiagnosed. A greater proportion of pre-school children (37 cases) and fewer adult patients (29 cases) was observed compared with the proportion we found. The estimated annual case rate was $2 \%$ of the practice population.

A twelve-month survey reported by four practitioners in Edinburgh (Knox, MacNaughtan, Laurence \& Robertson, 1967) concerned 589 episodes of diarrhoeal illness in 1966 and 1967. In two-thirds of cases no pathogen was revealed by bacteriological screening in the surgery. Of the remainder 106 yielded Sh. sonnei and one a salmonella. Blood and mucus in the stools did not distinguish Sonne infections, most of which were in children aged 1-9 years. Fifty-seven per cent of patients were under 10 years old and $13 \%$ were 40 years or over, compared with corresponding figures of 45 and $23 \%$ in our study. The population at risk and therefore the case rates were not given.

The bacteriological findings in these three surveys were not dissimilar to this study of laboratory results. Most cases did not yield a pathogen and $S h$. sonnei was the most common significant bacteriological result, although this infection was not always prevalent. Sonne dysentery affected children and most of these were of school age. Blood and pus cells were observed about as often in Tuckman's series of cases as in ours, suggesting that our series was not selecting more severe cases. 
The annual incidence of consultation in two of these surveys was 2 and $5 \%$ of the population. The annual incidence of our laboratory index cases fluctuated within a two-fold range and averaged $0.46 \%$ while the total of new cases must have been greater. A greater proportion of cases in young children in the surveys referred to may be accounted for by younger series and the fact that we studied index cases. Young children are frequent victims of home contact and would increase the number of consultations without adding to the number of index cases, or, in many instances, of laboratory examinations.

In the U.S.A. a study of illness in a group of families in Cleveland (Hodges $e t$ al. 1956) showed the annual incidence of gastroenteritis to be between 1 and $2 \%$, with the same predominance of male children and female adults. The presence of school children in a family increased the case rate. Again the age distribution included a greater proportion of young children than that seen in our laboratory investigated index cases. Gastroenteritis and respiratory symptoms were sometimes associated (McCorkle et al. 1956).

Tuckman and his colleagues were unable to find obvious clinical grounds for diagnosing their patients and only the laboratory results distinguished $S h$. sonnei infections from other conditions. In Enfield, during the 16 years of our study, the general practitioners received from the laboratory a positive report of some kind of abnormality in nearly one third of cases, but the proportion varied with age and with time. Of the positive findings $70 \%$ indicated an infection.

Sonne dysentery affected the community in waves, a phenomenon also noted in Scotland (CDS, 1973). The pattern of Sonne-diagnosed cases in Enfield was reflected in corresponding rises in undiagnosed cases. It has been shown that this laboratory was $92 \%$ successful in isolating $S h$. sonnei from an infected case. The rate was initially higher but fell if the patient had already had symptoms for a week or more (Tillett \& Thomas, 1974). The fact that the number of undiagnosed cases also increased proportionally during epidemics of Sonne dysentery cannot therefore be attributed to failure to isolate $S h$. sonnei. It seems likely that the concern of general practitioners to diagnose dysentery correctly when it was known to be abroad in the community made them refer more of their diarrhoeal patients for laboratory diagnosis during an epidemic. Both the laboratory and the public health department encouraged practitioners to diagnose cases of dysentery bacteriologically. This was part of a policy which attempted to prevent and control school outbreaks (Thomas \& Tillett, 1973b).

Salmonellosis was often notified to the Registrar General as food poisoning. It was a much less common finding than Sonne dysentery, affected all age groups and was more common during the summer months. A detailed account of cases and their household contacts has been reported (Thomas \& Mogford, 1970).

The $E$. coli infections in young children were decreasing in number during these years although, in fact, the number of enteropathogenic serotypes recognized, for which sera were available, was increasing. The role of $E$. coli as an agent of diarrhoea in older persons is now under review. Strains have been associated with travellers' diarrhoea (Rowe, Taylor \& Bettelheim, 1970), illness in American soldiers in Vietnam (Dupont et al. 1971) and episodes of food poisoning (P.H.L.S., 
1974). As long ago as 1949 a report was published of a school outbreak of gastroenteritis associated with a paracolon bacillus now identified as E. coli 0124 (Hobbs, Thomas \& Taylor, 1949). The seven older sporadic cases of $E$. coli infection reported in this present series of patients were found during two years of special study.

Apart from these seven, 76 'other' bacterial infections were reported. These were locally unusual pathogens (e.g. Sh. flexneri) or not routinely sought from index cases (e.g. Staph. pyogenes, Cl. uelchii) or species seldom reported such as providence species (Ridge \& Thomas, 1955) or arizona species (Thomas, 1957).

Microscopy was part of the routine laboratory investigation and increased the diagnosis rate. Giardia lamblia was found sporadically in $1.4 \%$ of patients of all age groups, with a slight excess in males which has been reported elsewhere (Carswell, Gibson \& McCallister, 1973). Although not common, Giardia has been reported in diarrhoeal outbreaks among children (Ormiston, Taylor \& Wilson, 1942) and among adult travellers (Thompson, Karandikar \& Leek, 1974). The number of Giardia infections diagnosed increases when duodenal material can be examined in addition to faeces (Petersen, 1972). Other parasitic infestations were also detected.

Microscopy allowed blood and pus cells to be observed and reported. Among the undiagnosed cases $13 \%$ of first specimens revealed inflammatory cells. Such patients were usually followed up for a repeat specimen in case a pathogen might be found subsequently or to indicate investigations for other causes of inflammation. This was considered particularly important in older patients and it was the routine to look for occult blood in patients over 40 years of age. These practices led to diagnosis of some cases of carcinoma, diverticulitis, colitis, peptic ulcer and piles.

The 1365 'fatty diarrhoea' cases were also detected by microscopy. The agent, possibly viral, responsible for these cases remains unknown. That diarrhoea with these characteristic stools can be infectious in nature was clearly demonstrated (Thomas, 1952). It is also described in a study of diarrhoea in infants under two years of age reported from the same laboratory and covering the years 1952-4 (Thomas \& Charter, 1956). The disease was most frequent in pre-school children, but was observed in all age groups. Cases were seen all through the year, but there was a winter predominance. This diagnosis should protect patients from misapplication of antibacterial drugs which appear to be ineffective in treatment.

We showed that $14 \%$ of salmonella and $4 \%$ of Sonne index cases were diagnosed in hospital (Thomas \& Tillett, 1973a), but our present series of index cases of gastroenteritis does not include these severer cases. But studies of patients admitted to hospital because of severe gastroenteritis have shown that only a small proportion yielded a causative pathogen (Sinha \& Tyrrell, 1973).

The question remains as to the cause of the greater part of diarrhoeal disease. There was a winter excess of such cases in this 16-year series. Part of the observed seasonal pattern may be an artifact created by the Sonne dysentery epidemics which occurred mainly in winter and which resulted in more 'undiagnosable' cases being referred to the laboratory as well. Indeed in years without much Sonne dysentery the number of undiagnosed cases tended to be greatest during the autumn quarter. Obviously it cannot be assumed that all undiagnosed cases had 
diarrhoea as a result of infection, but unrecognized infective agents must be considered. In many years outbreaks of unexplained gastroenteritis affected schools. Faeces specimens were examined and food poisoning also considered, but findings were wholly negative. It was found in practice that the routine exclusion of affected children, pending laboratory investigation, was followed by a rapid reduction in the incidence of new cases. Although recognized viruses have been recovered from the faeces of only a small proportion of cases of sporadic gastroenteritis (Cramblett \& Siewers, 1965) filtrate transmission from outbreaks in which no pathogen was isolated has been demonstrated repeatedly (Fukumi et al. 1957; Buscho et al. 1973). There is an increasing number of reports of the association of gastroenteritis with the presence of specific viral particles in the faeces (Murphy, 1964; Clarke et al. 1972; British Medical Journal, 1972; Middleton et al. 1974; Sexton et al. 1974).

It has been shown that much of the considerable fluctuation in undiagnosed cases of diarrhoea may be explained by the Sonne dysentery epidemics. But a third of the fluctuation remains unexplained and we suggest that this was associated with changing prevalence of unrecognized infectious agents.

Our thanks are due to the General Practitioners and Medical Officers of Health and their staffs who co-operated in this study in Enfield. We are also grateful to the technical staff of the one time Edmonton Public Health Laboratory, especially the late J. H. Cowlard, to Miss Jane Broker for much clerical assistance and to others in the Epidemiological Research Laboratory.

\section{REFERENCES}

British Medical Journal (1972). Viruses of vomiting. British Medical Journal iv, 442.

Buscho, R. F., Wyatt, R. G., Dolin, R., Blacklow, N. R., Dupont, H. L. \& Chanock, R.M. (1973). Recurrent institutional outbreaks of acute infectious nonbacterial gastroenteritis : epidemiology and etiology. American Journal of Epidemiology 98, 192.

Carswell, F., Gibson, A. A. M. \& McCallister, T. A. (1973). Giardiasis and coeliac disease. Archives of Disease in Childhood 48, 414.

Clarke, S. K. R., Cook, G. T., Egglestone, S. I., Halt, T. S., Miller, D. L., Reed, S. E., Robenstein, D., SmtTh, A. J. \& Tyrrell, D. A. J. (1972). A virus from epidemic vomiting disease. British Medical Journal iii, 86.

CDS (1973). Shigellosis in North East Scotland (1929-71). Communicable Diseases (Scotland) Report 73/7, iii.

Cramblett, H. G. \& Siewers, C. M. F. (1965). The etiology of gastroenteritis in infants and children, with emphasis on the occurrence of simultaneous mixed viral-bacterial infections. Pediatrics 35, 885.

Department of Education and Science and Department of Health and Soctal Security (1971). Memorandum on the Control of Infectious Diseases in Schools. London: H.M.S.O.

Dupont, H. L., Formal, S. B., Hornick, R. B., Snyder, M. J., I.ibonati, J. P., Sheahan, D. G., LaBrec, E. H. \& Kalas, J. P. (1971). Pathogenesis of Escherichia coli diarrhoea. New England Journal of Medicine 285, 1.

Fukumi, H., Nakaya, R., HatTa, S., Noriki, H. \& Yunokr, H. (1957). An indication as to identity between the infectious diarrhoea in Japan and the afebrile infectious non-bacterial gastroenteritis by human volunteer experiments. Japanese Journal of Medical Science and Biology 10, 1 . 
Hoвbs, B. C., Thomas, M. E. M. \& TayLor, J. (1949). School outbreak of gastroenteritis associated with a pathogenic paracolon bacillus. Lancet ii, 530 .

Hodges, R. G., McCorkie, L. P., Badger, G. F., Curtiss, C., Dingle, J. H. \& Jordan, W. S., JNR. (1956). A study of illness in a group of Cleveland families. XI. The occurrence of gastrointestinal symptoms. American Journal of Hygiene 64, 349.

Knox, J. D. E., MacNaughtan, G., Laurence, A. R. \& Robertson, A. A. (1967). Diagnosis of diarrhoea in general practice. Lancet ii, 1392.

Logan, W. P. D. \& Cushion, A. A. (1958). Morbidity statistics from general practice, Vol. I (General). Studies on Medical and Population Subjects, No. 14. London. H.M.S.O.

McCorket, L. P., Badger, G. F., Curtiss, C., Dingle, J. H., Hodges, R. G. \& Jordan, W. S., JNR. (1956). A study of illness in a group of Cleveland families. XlI. The association of respiratory and gastrointestinal symptoms: an estimation of the magnitude and time relations of the association. American Journal of Hygiene 64, 357.

Middleton, P.J., Szymanski, M. T., Abbott, G. D., Bortolussi, R. \& Hamilton, J. R. (1974). Orbivirus acute gastroenteritis of infancy. Lancet $\mathrm{i}, 1241$.

MURPHY, A. M. (1964). The isolation of an unclassified virus from an outbreak of infantile diarrhoea. Journal of Hygiene 62, 425.

Ormiston, G., TAYloR, J. \& Wilson, G. S. (1942). Enteritis in a nursery home associated with Giardia lamblia. British Medical Journal ii, 151.

Petersen, H. (1972). Giardiasis. Scandinavian Journal of Gastroenterology 7, supplement 14.

Public Health Laboratory Service (1974). Gastroenteritis from cheese. British Medical Journal ii, 2.

RidGe, L. E. L. \& Thomas, M. E. M. (1955). Infection with the providence type of paracolon bacillus in a residential nursery. Journal of Pathology and Bacteriology 69, 335.

Rowe, B., Taylor, J. \& BetTelheim, K. A. (1970). An investigation of travellers' diarrhoea. Lancet i, 1 .

Sexton, M., Davidson, G. P., Bishop, R. F., Townley, R. R. W., Holmes, I. H. \& Ruck, B. J. (1974). Viruses in gastroenteritis. Lancet ii, 355.

SrnhA, A. K. \& TyrRele, D. A. J. (1973). Changes in the clinical pattern of gastrointestinal infections in North West London 1968/70. British Journal of Clinical Practice 27, 45.

SmItHER, W. J. (1953). Gastroenteritis in general practice. A study of 90 unselected cases. British Medical Journal i, 376.

Thomas, M. E. M. (1952). 'Epidemic' abdominal colic associated with steatorrhoea. British Medical Journal i, 691 .

Thomas, M. E. M. (1957). Enteritis from tortoises. Monthly Bulletin of the Ministry of Health and the Public Health Laboratory Service 16, 29.

Thomas, M. E. M. \& Charter, R. E. (1956). The aetiology of juvenile diarrhoea. British Medical Journal ii, 339.

Thomas, M. E. M. \& Mogford, H. E. (1970). Salmonellosis in general practice. Observations of cases and their households in Enfield. Journal of Hygiene 68, 663.

Thomas, M. E. M. \& Tillete, H. E. (1973a). Dysentery in general practice: a study of cases and their contacts in Enfield and an epidemiological comparison with salmonellosis. Journal of Hygiene 71, 373.

Thomas, M. E. M. \& Tilletr, H. E. $(1973 b)$. Sonne dysentery in day schools and nurseries: an eighteen-year study in Edmonton. Journal of Hygiene 71, 593.

Thompson, R. G., Karandikar, D.S. \& LEeK, J. (1974). Giardiasis, an unusual cause of epidemic diarrhoea. Lancet $\mathrm{i}, 615$.

Tiluetr, H. E. \& Thomas, M. E. M. (1974). Culture of the faeces in the diagnosis of Sonne dysentery: a statistical method for estimating the true isolation rate. International Journal of Epidemiology 3, 177.

Tuckman, E., Chapple, P. A. L., Franklin, L. M., Manser, I. N., Woodall, J. T., Randalt, K. J. \& McDonald, J. C. (1962). Acute gastrointestinal illness in general practice. British Medical Journal i, 135.

Walker, A. B. \& Robertson, W. (1968). Enquiry into incidence of diarrhoeal diseases in the working population in Edinburgh. Health Bulletin. Scottish Home and Health Department $26(4), 55$. 